\title{
(Southern) Urban, American Education: Myths and Methods
}

\author{
Rosetta Codling ${ }^{1 *}$
}

${ }^{1}$ Georgia Military College, 255 Veterans Parkway, Fayetteville, Georgia, USA

*Corresponding Author: Rsi4784212@aol.com

Citation: Codling, R. (2019). (Southern) Urban, American Education: Myths and Methods. Mediterranean Journal of Social \& Behavioral Research, 3(2), 17-23. https://doi.org/10.30935/mjosbr/9589

\begin{abstract}
The advent of urban education, in America, brought about the recognition of the cultural and environmental 'cognitives' as they relate to students in industrialized states. The imperatives surrounding the education of these students require that educators factor diverse cultural identities, languages (foreign and dialects), 'challenged' economic situations, and limited funding for public education into their curriculum planning. The new frontier of Southern, urban education is looming before pedagogy and administrators presently. America's Southern regions are booming with population and economic growth. Currently, the primary and secondary schools of the Southern regions rank poorly against their Northern counterparts. These (newly) recognized urban students lack fundamental proficiency in math, English, and Science. Most are IT illiterate. The deficient practices of the schools that educate or mal-educate these pupils must be acknowledged and hopefully changed.

This paper seeks to explore the role historical elements of urban education and the methodologies (successful and non-successful) that are part of this discipline. Southern, urban education and the different and/or similar practices (past and present) will be explored with a focus upon the new challenges within.
\end{abstract}

Keywords: Horace Mann School of Thought, John Dewey Education theories, Booker T. Washington Education theory, The Talented Tenth, Education 'tracking', Brown v. Board of Education, Civil Rights Act of 1964

Received: 19 Jan. 2019 • Revised: 31 May 2019 • Accepted: 11 Jul. 2019

\section{INTRODUCTION}

America is a vast continent. The educational systems within the continental, United States take form in vastly unique ways. Still, history indicates that early, American, educational philosophy and policy can be traced the Horace Mann School of thought. Mann continues to impact upon educators and politicians to this very day. Horace Mann attended a one room school house, as a primary student. His early education in impoverished settings and lacking in adequate resources drove him to seek to improve the quality of public schools. He devoted his life to improving and establishing a better, free system for all students. Mann's polices centered upon character development with an emphasis on reading, writing, and arithmetic ('PBS Online: Only A Teacher," 2015). This school of thought became the basis for future educational thought throughout America. During Mann's times, few children could attend school and fewer minorities (blacks and Americans Indians) had the ability to reap the benefits of a formal education. The rich educated their young, privately, and the poor struggled to merely clothe and feed their young. The education of blacks was prohibited in the South. Severe penalties were evoked against those who educated blacks and those educated blacks could be killed during the time of slavery. The impact of acts which operated as educational prohibitions served to inhibit the learning process of the poor and minorities.

\section{METHODOLOGY: An examination of educational theories and legislative acts through the course of American history from 1884-2015.}

\section{Horace Mann Educational Thought}

In the post- Horace Mann period, The American Reconstruction Era, many changes included the advent of new education policies in Southern regions ("The History Channel: Carpet Baggers and Scalawags," 2015). Mann was a Northerner born in Massachusetts and remote from the Southern experience. During The Reconstruction Era, most (attempted) positive changes were abruptly thwarted and/or never realized. Northerners harbored resentment over the South for the pain, sufferings, and losses sustained as a result of the Civil War. This disdain for the South prompted the reluctance of many to render assistance. Many capitalized upon the vulnerability and rejected state of the Southern regions. Carpetbaggers (Northerners) and Scalawags (white Southerners) equally took advantage of the weakened Southern economy and people. Together, these factions ravaged Southerners. During the upheaval of these times, complex and multi-tiered educational policies were enacted which governed the course of Southern education. It is to be noted that current policies (which impact upon African American educational systems) stem directly from The

( 2019 by the authors; licensee MJOSBR by Bastas, Cyprus. This article is an open access article distributed under the terms and conditions of the Creative Commons Attribution License (http://creativecommons.org/licenses/by/4.0/). 
American Reconstruction Era. White schools were seriously underfunded and black schools were less or never funded. However, it must be noted that some 'self' education among blacks did take place. Those blacks with an education endeavored to teach other blacks. Black churches became schools, by night, and the age of the pupils spanned from the very young to the very old ("Black towns, established by freed slaves, are dying out," 2015). Compassionate whites (some Abolitionists and Northern philanthropists) personally aided in teaching the newly freed. And in no other period of American history did so many blacks seek and struggle to read and write. Freedom and literacy were the dreams of the enslaved.

Most monies appropriated to Southern regions, by the government, were meant to finance the redevelopment of infrastructure, communities, and educational institutions destroyed by the Civil War. Tragically, these monies were often diverted, embezzled, and lost through greedy, self-serving individuals before ever reaching the needy parties. Most importantly, the Southern economy based upon slavery was destroyed ("The South After The Civil War: Chapter 15," 2015). As a result, the Southern poor became poorer. The uneducated found it hard to get work as sharecroppers because the farmers had difficulty getting financing for their farms. Southern rural or urban education came under the dominion of the North (through funding). Educational theory and policy remained stagnant and conveniently rooted in Horace Mann theories which were dependent upon federal funding for implementation. As usual, money dictates the level, quality, and extent of one's education in any region...especially so during The Reconstruction Era of the South. Horace Mann realized these injustices years before. Southern pupils suffered badly after the Civil War because of limited or non-existent funding for public schools. Timothy Thomas Fortune was a forerunner in connecting economics and education with the legitimacy of residency for blacks in mainstream, American society. His treatise, in the form of his book, Black and White: Land, Labor, and Capital in the South (1884), is the companion and equal to the British manifesto The Wealth of Nations (1776), by Adam Smith. Adam Smith's classic surveys and critiques the basis and fundamentals for Western Capitalism as being facilitated by cheap labor. Timothy Fortune's classic surveys and critiques the individuals which comprise the labor force as being poor whites and blacks...equally exploitable for Capitalist purposes in America. As Timothy Fortune's career advanced, he left the South to pursue more opportunities in journalism and writing in the North. A permanent resident of the South, Booker T. Washington, became the forerunner in terms of developing philosophical educational and economic policies for the emerging freedman. Booker T. Washington's own classic Up from Slavery (1901) provided a concrete plan and the methodologies for Southern blacks and indigenous peoples to advance. But, Booker T. Washington's views came not without contest. W.E.B. Dubois, of the Northern hemisphere of intellectual thought and policy towards the new negro, offered a different position and methodology for the education of blacks which clashed with Booker T. Washington's objectives (“Locke and the New Negro," 2015).

\section{Booker T. Washington School of Educational Thought}

Booker T. Washington was born into slavery, in the hostile Southern region (1856-1915). He knew no security, only the harsh reality of racial hatred. Aware of this truth, Booker T. Washington pursued educational and professional goals which would not clash with Southern whites. He worked his way to attend Hampton Institute to study. Hampton offered 'skill' study in trade and farming. These skills were necessary in a developing South. Washington rationalized that Blacks, through necessity, stood a chance to flourish and remain alive; if they possessed fundamental skills, not liberal arts. The demand for trades and agricultural skills was so great that conflict could be averted. Of course, a segregated community for blacks would be the trade-off. Most whites did not possess extensive education in the South or the North. Poverty bridled the aspiration and ability of most to pursue extensive education. Timothy Thomas Fortune concluded that white, poor children were needed to contribute to the family income as farmers or participants in the migrant labor force of the South. Poor children could not be sacrificed to sit in a classroom for lengthy periods. Southern school terms, to this day, commence in August and terminate in early May. This time frame was enacted to accommodate the children of farmers who were needed on the farm in springtime. The practice of permitting a child to extend his/hers education beyond the primary stage was referred to as 'spoiling' a child. Only 'monied' families could afford this luxury. An educated black, sponsored by the means of a wellto-do, black family, would be an enigma and seen as an offense and threat to whites in the South. Furthermore, a formally educated black seeking employment (in any sector of a limited, Southern economy) would be an object of envy. Those who despised educated blacks might hurt or lynch such individuals.

\section{W.E.B. Du Bois school of Educational Thought}

W.E.B. Du Bois was born into a Northern, middle class, black family in Massachusetts (1868-1963). There were funds and a safety cushion provided for many blacks born in the Northern, hemisphere of America. Du Bois went fearlessly and pursued opportunities. The sponsorship of family afforded him the opportunity to have the basic needs for food and shelter met. He would also benefit from his family sponsoring aspirations in terms of formal and higher education. W.E.B. Dubois benefited well and exhausted every possible opportunity that was presented to him. He attended the prestigious, black, Fisk University for his undergraduate education. He was the first African American to obtain a $\mathrm{PhD}$ from Harvard University. Cultivation and further grooming were accessible to Du Bois. He also studied at the University of Berlin. This form and mode of education was exclusive and few whites could access such opportunities in the South. In fact, white Southerners preferred their sons to attend Princeton University, as opposed to Harvard or Yale, because of Princeton's links to Southern politics and politicians. Originally, Du Bois' application to the more liberal Harvard University was rejected because of his Fisk University degree. Black institutions of education were considered sub-standard because of racist views. Eventually, Du Bois was accepted and permitted to study at Harvard. At one point in Du Bois' career, Atlanta, Georgia, was a point of destination. Du Bois seized a coveted offer to teach at Atlanta University, as a professor. Although, Du Bois had taught in the North, few Northern universities rivaled the status of Atlanta University for a black academic. His honored work Souls of Black Folk (1903) was a landmark treatise which outlines his philosophy and hopes for equality for blacks through academics. The concept of Double Consciousness for blacks is outlined in Du Bois' text.

Policies vs. Law (The Atlanta Compromise of 1894 and the Plessy vs. Ferguson Supreme Court ruling)

Booker T. Washington's fundamentalist, educational policies stemmed from the reality of his own environment. The Classics, the Arts, and Rhetoric served not communities striving to regain a foot hole 
in the scheme of American economics. Masons, carpenters, and farmers were basic and essential to the Southern community. Work could be found more readily by possessing trade skills. Blacks could also survive and thrive in cellular circumstances outside of white compounds with enough money derived from regular work. Segregation, as opposed to death, was a preferable alternative for freedmen. Washington negotiated policy into a fully, functional agreement called The Atlanta Compromise ("Booker T. Washington Delivers the 1895 Atlanta Compromise Speech," 2015) This agreement paved the way for black, economic, achievement, in Atlanta, un-rivalled by any other American city to this day. Booker T. Washington, further, transferred his ideas into real educational formats during his tenure as head of Tuskegee University. Not surprisingly, money was donated to Booker $\mathrm{T}$. Washington from white philanthropists. Washington, according to Mark Bauerlein in his critique "The Tactile Life of Booker T. Washington," 2008), was skilled at generating revenue. Many donors to the cause of Booker T. Washington were white and from the North of America. Yet, many white donors were Southerners that saw that segregated study was favorable for their purposes. The Land Grant Colleges Act of 1862 lead to the establishment of venues for the study of agriculture and mechanical arts. Separate domains for blacks (HBCUs) and American Indians were enabled through the Morrill Land Grant Act. This government provision specified that equal access to blacks and Indians to high education must be provided or the establishment of services (separately) for their use. Many states preferred to provide separate colleges and universities for their use ("The History of Historically Black Colleges and Universities,"2015). The famous case of Plessy vs. Ferguson, in 1896, legally sanctioned segregation in public schools. And, it was not until the famous Brown vs. Board of Education ruling, by the American Supreme Court, that the separate but equal policies were deemed illegal. Still, those rogue states which opposed the new ruling held education hostage by totally closing public schools. For example, in Prince Edward County, Virginia (1959), the entire school system was closed for five years in defiance of the law ("Brown at 60: The Southern Manifesto and "Massive Resistance to Brown," 2015). White children, with monied families, were privately educated. Most of the black student population lacked schooling for five, long years because the public schools were their only source for education. Notorious school districts in Norfolk, Charlottesville, and Warren County halted the implementation of Brown vs. The Board of Education by making school attendance personal, noncompulsory and a choice. And the landmark Supreme Court verdict, on education, enabled the future methodology of 'tracking' and designating specific curriculum for lower level, commercial, and academic students, in America and England too. The perception of many became that some students (of certain castes) were best suited for certain levels of education (Kohli, 2014). W.E. B. Du Bois adamantly disagreed with such theories and perceived that such educational policies stymied the progress of the black race.

A proponent and recognized member of New York's Harlem Renaissance movement, Du Bois, theorized the educational and philosophical theory of The Talented Tenth ("W.E.B. Du Bois: The Talented Tenth Speeches 1-4,” 2015). The educated blacks (which represented ten percent of the black populous) would avail themselves to the other ninety percent and mentor their education and eventual advancement, according to these principles of Du Bois.

Northern and Southern educational practices and premises remained segregated by class and race for most of the years which preceded the historic case of Brown vs. the Board of Education. Exclusively, overt politics, economics, and racism dictated the course of education in the South. In the North, covert politics, real estate (redlining), economics, racism, and fear dominated the course of education. Homer Hoyt is credited with a fact based study of the illegal, real estate practice in his 1934 dissertation entitled: "One Hundred Years of Land Value in Chicago: The Relationship of the Growth of Chicago to the Rise Its Land Values, 1830-1933." His treatise assisted in enabling the real estate industry's racist practices further ("How We Got Here: The Historical Roots of Segregation," 2015). As a result, Northern and Southern schools of the rich and poor experienced a sanctioned, greater divide because of favor or disfavor through enhanced or impoverished funding from tax revenues.

The John Dewey Social Movement and School of Ed ucational Thought

As the conflicts between the educational philosophies of Washington and $\mathrm{Du}$ Bois raged on, mainstream progressive, educational thought for America focused upon a maverick named John Dewey (1859-1952). Dewey's theories gained prominence during the late 1800's and were cemented in the core of American educational thought by the 1900's. John Dewey, born in Vermont, was another Northerner with Northern educational, philosophical cadence. He spawned a new rhythm in terms of the linguistics, logics, and principles of education. He was a philosopher, by academic origins, but he extended his logistical range to make application with education. Experience was a prominent aspect of his views regarding methodology. Dewey valued the child as being the center. The educator, he advocated, merely expands upon the relative experience that the child presents before him/her. This philosophy and John Dewey was annexed fully by Teachers College/Columbia University ("John Dewey/American Pragmatist," 2015) Dewey appealed to elitists and the Avant-garde of Northern, educator circles. These factions accessed the methodology of John' Dewey and his theories were implemented widely. Still, with the acceptance of Dewey methodology, the omission of black pupils and Southern pupils (and their population, environs, and linguistics) was never accounted for by Dewey. Speakers of Northern AAE Urban AAE, Southern AAE, and Cajun were not factored into consideration in terms of linguistic impasses that might occur through misunderstandings. True, the Southern educational systems did not embrace new ideas quickly. The virtue of exposing students to aesthetic arts was a major component of Dewey's educational premises. But, Southern urban and rural communities had not the funds or established venues for their students to engage in aesthetic practices. As a result, Southern educational practices and methodologies remained stagnant in comparison to Northern counterparts.

The Brown vs. Board of Education verdict was a catalyst for the ensuing changes of the 1960's. In New York, public school teachers (through Albert Shanker) protested and formed a strong force as a union (UFT) for educator and pupil rights (“Albert Shanker," 2015). The policies of school busing and the integration of college campuses commenced after the landmark rulings from America's highest court on Civil Rights and education. Blacks, in the South, sought changes and justice against Jim Crow social codes ("A Brief History of Jim Crow," 2015). The Supreme Court's ruling against Jim Crow came with The Civil Rights Act of 1964 struck down separate, but equal practices. Also, this new act prompted social uprisings for the true realization of changes in primary and higher education. America did change radically. 
Economic growth, in America, provided for affluent, liberal thoughts in the 1960's. In fact, an advocate and legal defender of the SDS (Students for a Democratic Society), directly attributed the social consciousness of the students to John Dewy thought. Bernardine Dohrn, a member of the notorious Weathermen Underground group, participated in the university movement. Dohrn stated that John Dewey thought inspired student protests ("1998 Interview About 1968 Columbia Student Revolt with Ex-Weatherman Leader Bernadine Dohrn," 2009). Students in the South challenged laws which prohibited blacks from equal rights ranging from seating on public buses to eating in restaurants (Turner, 2011). White students, in colleges and universities, primarily, protested America's role in the Viet Nam war and academic affiliations in warfare research. The discovery of academic affiliation, in war research, at one of America's Ivy League institutes (Columbia University) lead to the seizing of campus buildings by students. Black students, on the same campus, protested discriminatory identification practices by campus security and the limited opportunities for other blacks to study there. The unrest spewed over to high schools and college campuses in New York, America, and the world. Student awareness fueled the social and academic change in the 1960's. It is to be noted that The Civil Rights Act of 1964 was aided and abetted by the sacrifices of white and black students. Still not all educational injustices were eradicated through the protests.

\section{Real Estate Politics, and Minority Representation in Education}

In the 1970's, red-lining and segregation became institutionalized. There were many innovative changes in curriculum, in Northern schools, which catered to student development. As a result, major and minor courses of study (similar to the academic casting in colleges and universities) were offered on the Middle and Secondary levels within public schools. Yet, in keeping with old separatist practices, suburban school districts (in the North and South) became hostels for whites to escape problems caused poverty and neglect in the public school sector. Families with money could pay the higher taxes required in suburban communities. Much of this money was funneled into better schools and the salaries to attract the best educators. Suburban schools were modern, well-equipped, and endowed with a lower student-to-teacher ratio. Students were 'tracked' to attend colleges. Most black students attended seriously underfunded schools in impoverished settings. Teachers, in urban areas, were inexperienced (waiting to gain enough experience to escape to the suburban school districts). The urban schools, also, lacked books and supplies. Few black students were advised to attend college and most courses in their schools lacked depth (Ogbu, 2003). Open Enrollment, a concept of freeing university admission to all students, benefited the white children of blue collar workers, mostly (Lavin \& Alba \& Silberstein, 1981). Black students were underrepresented at public universities and colleges in the North and South. There were even fewer blacks attending private universities and colleges in America. This may be the result of the lack of preparation and courses to prepare black students for collegiate education (Ogbu, 2003). The disparity between black, white, North, and South education grew. The fervor of the people and students to be instigators of change tempered. Economic climates across the globe changed for the worst as the first major recession in America occurred in the mid 1970's. Jobs became scare, unemployment rose, and political awareness an activity became second to survival.

\section{Shifting Focus to Economics versus Educational Policies}

By the early 1980's, educational, progress was slowed by the economics of the times and things settled downward. Americans were continuing to grapple with an economic downturn. Teacher recruitment and salaries were low. Attrition was used as a tool to free school districts (in the North) of expensive, tenured, elder staff without union backlash. Incentives for voluntary, early retirement were offered to seniors and this depleted schools of the most skillful staff. An imbalance in terms of maintaining the quality of education rendered to students surfaced. Also, the mentoring of new teachers became difficult because of a lack of seasoned staff to do so. School buildings were crumbling and ill maintained because there was no money to do so. Yet, politicians in self-aggrandizing platforms, argued for standardization of public education in America. The Reagan administration commissioned the report A Nation at Risk (1981), this report touted reform in the form of developing transitional sequence of courses for secondary school curricula ("A Nation At Risk: The Imperative For Educational Reform,” 1983). This new agenda was sensitive to student needs and the call to adequately attract and compensate good teachers. Yet, regional and linguistic variations across the nation were not adequately addressed in this study. Violence and the lack of classroom management became the concern of parents and the public in the 1990's. Funding was allocated to school security in urban areas where crime escalated on school premises. Parents sought refuge in the concept of charter schools. Suburban parents argued for home schooling and/or vouchers to offset the cost of private schools. Teacher unions fought vigorously against shifting student populations to private arenas. Political forces pandering to poor parents weary of the decline of the public schools conceptualized the No Child Left Behind Act (No Child Left Behind: Elementary and Secondary Education Act, 2001). With this act, fundamental, educational propaganda was economized into concrete legislation. This act aimed at pacifying frustrated, poor parents seeking a better education for their children in public schools. The main focus of the act was "standards, assessment, and accountability." Middle class defection from public schools occurred long ago. The loss of the educated, monied middle class from public education contributed to the demise of the public school system. Public education was now servicing mostly black and immigrant populations which were unaware and aloof from the role of parents and parenting through PTAs (Parent Teacher Associations). The blame for student failure was placed upon the schools and the teachers. Achievement disparities were visible in the testing scores between black, white, Southern, and Northern populations. Salvation, channeled by the politicians, was to be realized through balanced lessons and formats in all American schools. The American Republican party took up the cause for improving education under George W. Bush. Little educational theory was incorporated into this new agenda. Southerners adamantly supported the simplicity of this new initiative. The state of Georgia's own, political representative, Newt Gingrich, was a proponent of No Child Left Behind. In accordance with Republican policies, states (not the government) gained more control to set standards for education through the No Child Left Behind Act. And the new method for obtaining student success centered upon accelerated testing. The vital role of parent participation and intervention, in conjunction with teachers, was not factored into the equation of achieving student success. Inherent participation within the educational process by middle class parents in public and private schools contributed to the success of their children in the past. The No Child Left Behind Act industrialized teaching and focused upon solely improving 
test scores. Schools which aiding in the false validity of the theory (through whatever means) were rewarded with enhanced funding to such schools and incentives for the salaries of administrators and a few teachers. Schools which continued to falter and disprove the credibility of the propaganda of No Child Left Behind were admonished and obtained demoted ratings. Poor ratings rendered diminished funding and eventual closure of poor schools. Rankings and documentation of failing schools were tools for political forces to further propagandize and dismiss concrete solutions.

\section{Politics and Educational Policy}

Almost as soon as the act was pressed to paper, No Child Left Behind (2001) commenced a period of fear and deception in public education circles. Teachers and administrators worked under conditions which instilled fear and paranoia. The schools began issuing false progress reports and statistics to attest to the success of the new agenda. The city of Houston, Texas actually reported a zero dropout rate (Winelip, 2003). Superintendents in Houston pushed for districts to provide positive statistics to hide the true dismal state of affairs. Researchers and educators cited the flaws in the legislation that politicos did not. Diverse cognitive development/ levels of students combined with lack of support and sponsorship from the parents presented challenges in the face of the new act. Also, technology was playing a pivotal role in the educational process. Suburban schools and parents realized this and provided computers in the schools and homes with access. Black students did not possess the same level of access to computers in their schools and homes. Access to technology did not come into the scheme of the legislative act (Bainbridge, 2002). Educators and their students continued to suffer. Fear, as opposed to inspiration, reigned at staff meetings. Further, deceptive means were fashioned to alter state test scores to salvage jobs and reputations.

In the North, as well as the South, a dark cloud hovered over public education in America during this time. True education was bridled. Teachers taught to the 'test' without infusing any creativity or aesthetics. No allocations for such were appropriated in most state, mandated lessons. Yet, the sterile lessons still did not spawn the anticipated results. Falsified test scores were becoming mandatory by the edict of administrators. And the veil of deception was slowly being lifted, as parents discovered that many graduates of public schools were illiterate ('Years of Schooling Leaves Some Students Illiterate," 2009).

\section{Deceptive Practices to Justify Political Malpractice in} Education

One of the most notorious cases (involving cheating) surfaced in the Atlanta, Georgia, public schools system. The Atlanta Journal Constitution (2008) embarked upon an investigation regarding the miracle of improved testing in the state ("A timeline of how the Atlanta cheating scandal unfolded," 2015). This was the opening of the No Child Left Behind 'Pandora's Box.' President Obama instituted the Reform of the No Child Left Behind legislation in 2010. Waivers were granted to States for exemption. The flaws in the act were becoming more evident. The Atlanta Journal Constitution surged forward and researched other school districts, in America, with miraculous healing tendencies emanating from the policy of No Child Left Behind ("Cheating our children: Districts with suspicious patterns,” 2015). Indictments were eventually obtained against the Superintendent of Atlanta public schools, Beverly Hall, district leaders, and teachers. Beverly Hall, the Superintendent, was a credible suspect and (possible) scapegoat. She was from New York, an urban educator, and her new ideas and 'demands for results garnered suspicions among locals. A conspiracy was declared in the case against Beverly Hall and her administration and the questionable test scores. Charges of racketeering were put forth against the administrators and teachers. The court of public opinion blamed the teachers and the system for the theft of authentic education. And the public acquired the justice demanded with the convictions of the teachers on April $1^{\text {st }}$ of 2015. Tragically, Superintendent Beverly Hall died of terminal cancer in March of 2015. She died before the verdict was rendered. Southern justice, in terms, of education prevailed. The South did not acknowledge the errors in judgement within No Child Left Behind Act. The blame was directed toward the 'messengers,' those who were burdened with the task of implementing the act. No real, new educational reform exists to date in the state of Georgia . However, a new law nullifies the mandate for students to pass the GHSGT, Georgia High School Graduation Tests (Downey, 2015). The change can be attributed to Bill 91 in Georgia. Bill 91 maintains the consistent policy of the South. Educational theories and methodologies are not required. Progress can be legislated (Downey, 2015). New York City embarked upon an investigation into cheating by teachers and administrators in August of 2015 (Harris, 2015).

\section{CONCLUSIONS}

In essence, (Urban) Southern education is distinguished by the pivotal role of politics in the education. Booker T. Washington's Atlanta Compromise (1895) may have been a financial and social agreement, but the ramifications are evident in educational policy, in the South. Tracking, in education, commenced through Washington's own theories regarding vocations suited for freedmen. Race determined the quality of education in the South. Race determined the extent of funding for education. Segregation within education was a staple in the South. Jim Crow laws were legally effective in maintaining the balance until Brown vs. Board of Education (1954) and the Civil Rights Act of 1964. Unique methods were devised to cloak the disparities and justify the failures. The No Child Left Behind (2001) Act was a superficial gesture to balance the scales for the poor. Educators, in States with failing test scores, merely cheated and changed the scores in the 2000's. The No Child Left Behind Act was never held accountable for the problems and victims. In 2015, standardized tests for prospective graduates in Georgia were eliminated, by state legislation, and graduation rates falsely rose.

(Urban) Northern education is distinguished by ever changing philosophies. W.E.B. Du Bois and John Dewey schools of thoughts steer educators to recognize student cognitive development and individuality. Yet, tracking in accordance with class and race did occur. Red-lining, as opposed to Jim Crow laws, created borders to prohibit trespassing into wealthy, white school districts by blacks and minorities. Brown vs. Board of Education did not impact upon the segregated school systems. Middle class flight from the cities impoverished schools did impact, negatively, upon public schools. Failure was publicized by revealing the poor standardized test results obtained by urban schools. Attempts to 'save face' were initiated through the changing of test scores and permitting students to do extensive 'back tracking' through makeup work and altered grades. The No Child Left Behind Act merely contributed to the negative categorization of failing students and schools. But, no real changes occurred to bring about changes. But, positive graduation rates were attainable through cheating and 
concessions that permitted students to make-up arrears at the last minute.

In the case of the North and South in America, education is propelled, currently, by the need to achieve positive results through any means necessary. Historically, the quality of American education, North or South, appears to be less important in contrast to the need for a cosmetically, positive outcome. Politics fashion the course and control the outcome of the theory.

\section{REFERENCES}

"John Dewey, American Pragmatist," Date extracted: September 5, 2015. Retrieved from: http://dewey.pragmatism.org/

1998 Interview About 1968 Columbia Student Revolt with ExWeatherman Leader Bernardine Dohrn--Part 3, (2009). Extracted on September 5, 2015. Retrieved from: http://bfeldman68.blogspot .com/2009/05/1998-interview-about-1968-columbia_19.html

Atlanta Journal Constitution., (2015). "A timeline of how the Atlanta cheating scandal unfolded," Education, Extracted on August 29, 2105, Retrieved from: http://www.ajc.com/news/news/atimeline-of-how-the-atlanta-school-cheating-scan/nkkLH

Bainbridge, L. William. (2002). "Commentary: Leaving Children Behind.” Technos Quarterly. Summer 2002 Vol. 11 No.2. Extracted on: September 5, 2015. Retrieved from: http://schoolmatch.com/ articles/technos.htm

Bauerlein, Mark, (2003). "The Tactile Life of Booker T. Washington." Retrieved from: https://www.chronicle.com/article/the-tacticallife-of-booker-t-washington/

Behavioral Research and Teaching (University of Oregon), Chapter 15: The South After the Civil War (2015) Retrieved from: http://www.brtprojects.org/cyberschool/history/ch15/15answers .pdf September 8, 2015

Brown, L. DeNeen. Black towns, established by freed slaves after the Civil War, are dying out. (2015). The Washington Post. Retrieved from: http://www.washingtonpost.com/local/black-towns-establishedby-freed-slaves-after-civil-war-are-dying-out/2015/03/26/ 25872e5c-c608-11e4-a199-6cb5e63819d2_story.html

Consitutional Rights Foundation, “A Brief History of Jim Crow.” Date of extract: September 5, 2015. Retrieved from: http://www.crfusa.org/black-history-month/a-brief-history-of-jim-crow

Downey, Maureen, (2015). “Opinion: New Georgia Law gives diplomas to those who didn't earn them," Maureen Downey@AJCGetSchooled.com, Atlanta Journal Constitution.Com, Extracted on: august 25, 2015. Retrieved from: http://getschooled.blog.ajc.com/2015/04/01/opinion-is-it-fairto-hand-diplomas-to-students-who-never-bothered-is-this-anapril-fools-joke/

Downey, Maureen. (2015). New law would ignore test failures and award belated high school diplomas to 8,000,"MaureenDowney@ AJCGetSchooled.com, Atlanta Journal Constitution, Extracted on August 27, 2015, Retrieved on: http://getschooled.blog.ajc.com/ 2015/02/05/did-states-high-school-graduation-test-hurtstudents-was-it-a-bad-test/
Du Bois, W.E. B., Douglas, Frederick, Washington T. Booker., (2007). Three African American Classics: Up from Slavery, Souls of the Black Folk, and Narrative of the Life of Frederick Douglas. Dover Publications.

Fortune, T. Timothy. Black and White, Land, Labor, and Politics in the South (1856) Kindle Free App. Extracted on August 27, 2015, Retrieved from: http://www.gutenberg.org/files/16810/16810h/16810-h.htm

Harris, Elizabeth. (2015). "New York City Task Force Targets Cheating by Teachers and Principals," The New York Times, n.Y./Region, Extracted on August 31, 2015, Retrieved from: http://www.nytimes.com/2015/08/05/nyregion/new-york-citytask-force-targets-cheating-by-teachers-and-principals.html?_r=0

Harris, Sonia., Neiman, David. (1995). Only A Teacher. Teaching Timeline. Georgia Public Broadcasting. Multimedia timeline. Retrieved from: http://www.pbs.org/onlyateacher/timeline.html

History staff.com., "Carpet Baggers and Scalawags." (2010). A+E Networks. Retrieved from: http://www.history.com/topics/ american-civil-war/carpetbaggers-and-scalawags September 8, 2015.

Kohl, Sonali, (2014). "Modern-Day Segregation in Public Schools.” The Atlantic.com. Retrieved from: http://www.theatlantic.com/ education/archive/2014/11/modern-day-segregation-in-publicschools/382846/

Lavin, David (1981). “Rights Versus Privilege,” The Columbia Electronic Encyclopedia, $6^{\text {th }}$ edition, Copyright 2012, Columbia University Press. Date extracted: September 10, 2015. Retrieved from: http://www.infoplease.com/encyclopedia/society/openenrollment.html

Louis R. Harlan, ed., The Booker T. Washington Papers, Vol. 3, (Urbana: University of Illinois Press, 1974), 583-587.

My AJC (Atlanta Journal Constitution). "Cheating our children: Districts with suspicious patterns," Extracted on August 30, 2015. Retrieved from: http://www.myajc.com/news/cheating-ourchildren/districts/

NAACP Legal Defense Fund, Brown at 60: The Southern Manifesto and "Massive Resistance to Brown" Retrieved from: http://www.naacpldf.org/brown-at-60-southern-manifesto-andmassive-resistance-brown (September 9, 2015)

Ogbu, U. John, Black American Students in An Affluent Suburb: A Study of Academic Disengagement (Sociocultural, Political, and Historical Studies in Education) Routledge Press, Jan. 3, 2003

Public Ed For Parents. "Original text of 1965 ESEA Act (1965). Extracted on Sept. 10, 2015. Retrieved from: https://sites.google .com/site/publicedforparents/original-text-of-1965-esea-act

Purnell, Hannah, "The History of Historically Black Colleges and Universities: A tradition rich in history." CollegeView.com. Retrieved from: http://www.collegeview.com/articles/article/thehistory-of-historically-black-colleges-and-universities September 9, 2015.

Simon, Scott (2009). "Years of Schooling Leaves Some Students Illiterate," (Interview with author Beth Fertig, author of Why cant $U$ teach me 2 read, 2009). Public Broadcasting Atlanta, Extracted August 31, 2015, Retrieved from: http://www.npr.org/templates/ story/story.php?storyId=121374125 
The Commission on Excellence in Education. (1983).”A Nation At Risk: The Imperative For Educational Reform. Washington, D.C., Extracted on: Sept. 9, 2015. Retrieved from: https://www3.nd.edu/ $\sim$ rbarger/www7/nationrs.html

The Leadership Council. (2003). "How We Got Here: The Historical Roots of Housing Segregation,” Date extracted: Sept. 4, 2015 Retrieved from: http://www.civilrights.org/publications/reports/ fairhousing/historical.html?referrer=https://www.google.com/

The Library of Congress Researchers. "Topics in Chronicling America Plessy v. Ferguson (Jim Crow Laws).” Retrieved from: http://www.loc.gov/rr/news/topics/plessy.html

Turner, Matthew, (2011). Global Nonviolent Action Database. "Montgomery, Alabama students sit-in for U.S. Civil Rights, 1960," Extracted on September 10, 2015. Retrieved from: http://nvdatabase.swarthmore.edu/content/montgomeryalabama-students-sit-us-civil-rights-1960
United Federation of Teachers, "Albert Shanker." Date extracted: September 3, 2015. Retrieved from: http://www.uft.org/who-weare/history/albert-shanker

United States Department of Education. No Child Left Behind Act (1965). Extracted on September 10,

University of Virginia American Studies. "Locke and the New Negro" (2009), Retrieved from: http://xroads.virginia.edu/ MA03/ faturoti/harlem/collage/locke.html

Winelip, Michael. (2003). "On Education; The'Zero Dropout' Miracle: Alas! Alack! A Texas Tall Tale.” The New York Times Online. Extracted on Sept. 8, 2015. Retrieved from: http://www.nytimes.com/2003/08/13/nyregion/on-educationthe-zero-dropout-miracle-alas-alack-a-texas-tall-tale.html

WXTS Radio, (2013). "W.E.B. DuBois The Talented Tenth 1 of 4." Date extracted: September 9, 2015, Retrieved from: https://www.youtube.com/watch?v=bDp5FYxece 